\title{
ANALISIS NARASI NAJWA SHIHAB TERKAIT KOMENTAR HOTMAN PARIS (KAJIAN SEMANTIK)
}

\author{
Analysis The Narrative That Presented By Najwa Shihab Related To \\ Comment From Hotman Paris (Study Of Semantic)
}

\author{
Susanna Hutabarat \\ Universitas Negeri Medan \\ Jalan Williem Iskandar Pasar V Barat Medan Estate \\ susanbarat@mhs.unimed.ac.id
}

Tanggal naskah masuk 27 April 2018

Tanggal akhir penyuntingan 4 Juni 2018

\begin{abstract}
The purpose of this study was to analyze the meaning of the narrative presented by Najwa Shihab which received comments from Hotman Paris Hutapea. This research used qualitative descriptive method, because its purpose is to express the meaning of text. The result of this study prove that there is no element of insulting or degrading the good name of the presented by Najwa Shihab as presented by Hotman Paris. The narrative leads to the condition of not received justice from the state related to the case of splashing hard water.

Key words: Najwa Shihab, Novel Baswedan, semantic
\end{abstract}

\begin{abstract}
Abstrak
Tujuan dari penelitian ini adalah untuk menganalisis makna dari narasi Najwa Shihab yang mendapat komentar dari Hotman Paris Hutapea. Penelitian ini menggunakan metode deskriptif kualitatif, karena tujuannya untuk mengungkap makna dari sebuah teks. Adapun hasil dari penelitian ini membuktikan bahwa tidak ada unsur menghina ataupun merendahkan nama baik pemerintah dari narasi yang disampaikan oleh Najwa Shihab seperti yang disampaikan oleh Hotman Paris. Narasi tersebut mengarah kepada kondisi Novel Baswedan yang masih belum mendapat keadilan dari negara terkait kasus penyiraman air keras.

Kata Kunci: Najwa Shihab, Novel Baswedan, semantik.
\end{abstract}

\section{PENDAHULUAN}

Bahasa adalah fenomena kemaknaan dalam komunikasi antarmanusia di mana pun ia berada, kebermaknaan komunikasi inilah yang menjadi ciri khas bahasa sebagai satu isyarat komunikasi (Parera, 2004: 41). Dilanjutkan bahwa bahasa merupakan satu gejala sosial dan digunakan untuk komunikasi antarsesama manusia. Maka dapat diartikan bahwa bahasa merupakan suatu gejala sosial yang digunakan dalam berinteraksi dalam lingkungan sosial, dan tidak menutup kemungkinan berisi berbagai makna yang berkaitan dengan apa yang hendak dikomunikasikan. Namun kerap kali, penutur terperangkap dalam tingkatan makna bahasa yang digunakan. 
Maraknya

kesalahpahaman maksud dalam penggunaan bahasa di Indonesia seringkali memicu perdebatan sosial hingga permainan politik yang berujung lapor melapor polisi. Semisalnya kasus Basuki Tjahadja Purnama. Tersandung kasus yang ditetapkan sebagai penistaan agama karena mengutip salah satu ayat dari kitab suci, yang jika dikaji secara bahasa sesungguhnya belum termasuk penistaan agama, sebab maknanya bukan menista, tetapi menjadikan ayat tersebut seolah alat yang digunakan beberapa pihak untuk melakukan perusakan moral/mental "membodohi".

Kasus terbaru di jagat hiburan mengenai penggunaan bahasa ialah puisi Sukma. Puisi tersebut menjadi masalah ketika umat salah satu agama merasa tersinggung atas kata-kata dalam puisi tersebut. Kasus tersebut juga tidak lepas dari pelaporan kepada pihak kepolisian. Namun permintaan maaf dari Sukmawati Soekarno Putri menjadi akhir dari pemberitaan tersebut. Hal ini terkait rendahnya pemahaman masyarakat akan pemaknaan penggunaan tata bahasa.

Sebelumnya, pada tanggal 2 Maret 2018 media massa juga dihebohkan oleh aksi pengacara kondang, Hotman Paris Hutapea yang mengkritik Najwa Shihab terkait postingannya di media sosial instagram. Hotman Paris dalam komentarnya mengingatkan Najwa Shihab agar lebih hatihati dalam menyampaikan rangkaian narasi dalam acara Mata Najwa. Menurut Hotman Paris, Najwa dapat dituntut pelanggaran UU ITE.

\section{Gambar 1. Judul Berita Kasus yang Dirujuk}

\section{Hotman Paris Peringatkan Najwa Shihab tentang UU ITE, Gara-gara Kalimat Ini!}

Tribunnews.com

Diterbitkan : 02/03/2018 09:41

Najwa Hotman ITribunWow Kolase

(Sumber: wow.tribunnews.com/2018/03/02)

Seperti kita ketahui, Najwa Shihab dalam acara Mata Najwa selalu menyampaikan narasi singkat sebagai kesimpulan topik pembahasan di akhir acaranya. Kali ini, narasi yang disampaikannya mendapat teguran dari pengacara Hotman Paris karena dianggap melanggar UU ITE terkait intendesi pejabat negara. Tetapi bagaimana sesungguhnya makna dari narasi Najwa Shihab dikaji dari segi semantik?

Kesalahan-kesalahan berbahasa sering kali terjadi. Hal ini bisa saja dipicu akibat kekurangpahaman individu dalam menata bahasanya untuk mencapai suatu maksud. Sehingga, dirasa perlu untuk mengkaji kembali sebuah pernyataan sebelum disampaikan ataupun dipublikasikan ke media sosial. Bukan hanya dari segi kepantasan atau tidak, tetapi juga dari unsur semantik (makna). Dengan begitu, setiap bahasa yang dituturkan dapat dipahami sebagaimana mestinya oleh pendengar, dan tidak menimbulkan ambiguitas. Selain itu, untuk lebih memperhatikan sebuah pernyataan yang digugat oleh pihak tertentu dari segi kebahasaan. 
Ilmu yang mempelajari tentang makna suatu bahasa berwujud tulisan ialah semantik. Oleh karenanya, peneliti tertarik melakukan pengkajian makna terhadap narasi yang disampaikan Najwa Shihab dari segi semantik. Adapun pertanyaan yang ingin dijawab ialah, apakah narasi Najwa Shihab memiliki unsur menghina atau merendahkan nama baik pemerintah? Kemudian akan disesuaikan dengan UU ITE yang dimaksud oleh Hotman Paris Hutapea. Sehingga dapat dilihat, apakah benar pernyataan Najwa Shihab layak dituntut menggunakan UU ITE atau tidak.

Bahasa merupakan salah satu alat berkomunikasi manusia. Terlepas dari segala aturan dalam tatanan ilmu bahasa, bahasa memiliki eksistensinya sendiri, sehingga bisa digunakan dan dimaknai berbagai hal. Makna tersebutlah yang kemudian dikelola untuk menghasilkan komunikasi. Jika kita membahasnya dalam keilmuan, maka ilmu yang membahas mengenai kemaknaan ialah semantik.

Ada 5 fungsi bahasa (Leech, 2003: 65), yaitu informasional, ekspresif, direktif, fatik, dan estetik. Dalam kaitan peran sosial, ada tiga fungsi yang dipakai, yakni ekpresif, direktif, dan fatik. Bagaimana pembicara menyampaikan perasaannya untuk mempengaruhi orang lain dalam hal memelihara ikatan sosial. Sedangkan menurut Morris (Parera, 2004: 11) ada 4 macam tujuan penggunaan bahasa, yakni informatif, valuatif, incitif, dan sistemik dengan modus-modus tertentu, seperti designatif, aprasial, preskriptif, dan formatif.

Lyons (dalam Pelawi, 2009, 147) mengatakan bahwa, "Semantics is traditionally defined as the study of meaning." Crystal (dalam Pelawi, 2009: 147) mengatakan bahwa, "Semantics is a major branch of linguistics devoted to the study of meaning in language." Semantik merupakan salah satu cabang ilmu linguistik yang membahas mengenai makna dan simbolsimbol. Semantik (artikel publikasi Juniar, 2013) adalah ilmu yang mempelajari tentang makna bahasa, perkembangan dan perubahannya. Sejalan dengan pengertian semantik yang disampaikan oleh Lehrer (dalam Pateda, 2001: 6), yaitu studi tentang makna.

Pateda (Pateda, 2001: 15) juga menyatakan bahwa semantik sebagai ilmu, mempelajari kemaknaan di dalam bahasa sebagaimana apa adanya (das sein), dan terbatas pada pengalaman manusia. Morries (dalam Parera, 2004:11) menjelaskan mengenai semantik sebagai tujuan dari pengguna bahasa. Menurut Novi Resmini ada dua belas jenis makna,yakni makna sempit, makna luas, makna kognitif, makna konotatif dan makna emotif, makna referensial, makna konstruksi, makna leksikal dan makna gramatikal, makna idesional, makna proposisi, makna pusat, makna piktorial, dan makna idiomatik. Dengan landasan ini, peneliti mengkaji tujuan dari kalimat narasi Najwa Shihab menggunakan kajian semantik.

Penelitian terkait kajian semantik yang relevan dengan penelitian ini pernah dilakukan oleh Sella Prasanti (2015). Judul penelitian tersebut, yakni "Analisis Makna pada Kring Solopos Edisi Bulan November 2014: Tinjauan Semantik". Penelitian ini bertujuan untuk (1) mendeskripsikan makna konotatif yang terkandung dalam Kring Solopos edisi bulan November 2014, (2) mendeskripsikan makna denotatif yang terkandung dari Kring Solopos edisi bulan November 2014, (3) mendeskripsikan makna berdasarkan tinjauan semantik.

Selain itu, Netti Titin Juniar (2013) juga melakukan penelitian mengenai makna kontekstual pada iklan niaga di harian Analisa. Judul penelitian yang diambil ialah, "Analisis Makna Kontekstual pada Iklan Niaga di Harian Analisa Medan”. Tujuan dari penelitian ini ialah untuk menjelaskan makna kontekstual yang terkandung dalam iklan-iklan niaga di harian Analisa Medan.

Kemudian penelitian Ali Mahmudi (2015) dengan judul "Analisis Makna pada Status BBM (Blackberry Messenger) di Kalangan Remaja: Tinjauan Semantik". Penelitian ini bertujuan untuk memaparkan (1) jenis makna pada status BBM (Blackberry Messenger) di kalangan remaja 
dan (2) makna kalimat yang terkandung dalam status BBM (Blackberry Messenger). Penelitian ini dilakukan dengna metode kualitatif deskriptif.

Ketiga penelitian tersebut merupakan penelitian mengenai kajian semantik dengan metode penelitian deskriptif kualitatif. Sedangkan penelitian yang akan dilakukan ini bertujuan untuk menganalisis makna dari narasi Najwa Shihab menggunakan teori semantik. Kemudian meninjau apakah narasi tersebut melanggar UU ITE.

Penelitian ini sama-sama mengkaji penggunaan bahasa menggunakan teori semantik, namun pada objek data yang berbeda. Oleh karenanya, penelitian ini secara teoretis tidak jauh berbeda dengan penelitian-penelitian tersebut. Akan tetapi penelitian ini dapat membuka wawasan masyarakat mengenai penggunaan bahasa sesuai makna, serta memaknai pernyataan orang lain. Bukan sekedar analisis kemaknaan, juga ditujukan dalam persoalan kesesuaian makna dengan aturan-aturan yang berlaku di Indoenesia, terlebih menyangkut informasi teknologi elektronik (ITE).

\section{METODOLOGI PENELITIAN}

Penelitian ini menggunakan teknik deskriptif kualitatif. Teknik penelitian deskriptif kualitatif ialah teknik penelitian yang disajikan menggunakan deskripsi dan bukan data berupa angka-angka. Penelitian ini fokus pada objek yang diteliti, yakni kutipan narasi Mata Najwa dalam acara Najwa Shihab yang dikomentari oleh Hotman Paris Hutapea. DData yang diteliti diperoleh dari media massa elektronik.

Penelitian deskriptif yang dilakukan berusaha untuk melihat dan menganalisis makna dari narasi Najwa Shihab. Karena data yang diteliti berbentuk teks yang sebelumnya dinarasikan oleh Najwa Shihab, maka segi kontekstual pun perlu diperhatikan. Karenanya, metode yang cocok untuk penelitian ini ialah deskriptif kualitatif.

\section{HASIL DAN PEMBAHASAN 3.1.Data}

\section{Gambar 2. Narasi Najwa Shihab yang Dipersoalkan Hotman Paris}

(Sumber: wow.tribunnews.com/2018/03/02)

Mata itu sedang sakit dan melepuh, daya pandangnya terancam merapuh.

Retina bisa saja bikin ringkih, namun optimisme tak boleh menyisih

Tekad yang berapi dan hati penuh nyali, menjadi pandu menembus gelap korupsi

Publik jangan dianggap sebelah mata, kemarahan adalah energi tak terkira.

Jika hanya marah yang kami punya, kami akan marah demi negeri tercinta.

Kami adalah jutaan mata yang selalu nyalang, kepal tangan yang tak akan mudah tumbang

\subsection{Hasil dan Pembahasan}

Roswita Silalahi dalam artikelnya yang berjudul Makna dan Konteks dalam Bahasa
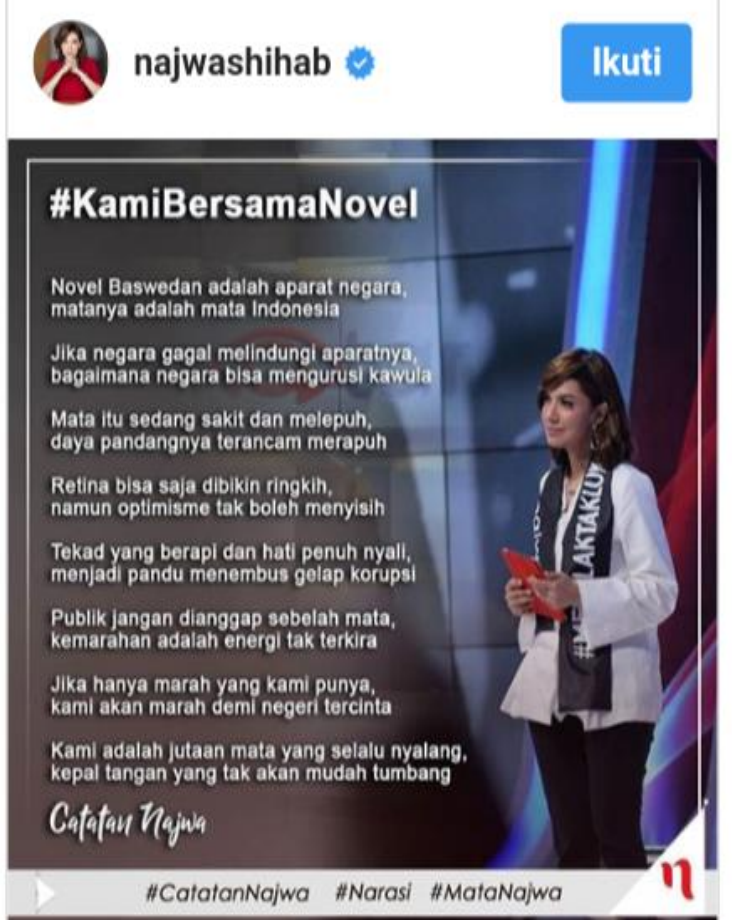

Batak Toba, menunjukkan makna semantik dalam bahasa Batak Toba jika diterjemahkan ke dalam bahasa Indonesia adalah sama (Silalahi, 2005: 10). Selain itu, makna semantik tidak dipengaruhi oleh kontekstual, karena merupakan pemaknaan teks tertulis. Demikian juga dengan data berupa narasi Najwa Shihab yang berbentuk teks tertulis 
akan dimaknai sesuai dengan makna yang sebenarnya tanpa konsep kontekstual.

Sebuah komunikasi dapat dimaknai apabila dilihat berdasarkan kalimat keseluruhannya. Ada tiga cara para filsuf dan linguis dalam upaya menjelasakan makna dalam bahasa manusia, menurut Abdul Wahab:

a. Dengan memberikan definisi hakikat makna kata

b. Dengan mendefinisikan hakikat makna kalimat

c. Menjelaskan proses komunikasi

Narasi Najwa Shihab yang mendapat kritikan dari Hotman Paris Hutapea adalah narasi penutup pada acara Mata Najwa edisi "Kami Bersama Novel". Mengingat kembali kasus yang menimpa Novel Baswedan pada tanggal 11 April 2017, yakni penyiraman air keras ke bagian wajah Novel. Namun hampir setahun berlalu, kasus tersebut belum juga menemui titik terang akan siapa dalang di balik semua itu. Hal tersebut menjadi alasan Mata Najwa menjadikan Novel sebagai narasumber. Selanjutnya akan dibahas mengenai makna narasi Najwa Shihab.

Tabel 1. Analisis Makna Narasi Najwa Shihab

\begin{tabular}{lrlr}
\hline \multicolumn{2}{c}{ Narasi } & \multicolumn{2}{c}{ Makna } \\
\hline "Novel & Baswedan & Novel & Baswedan \\
adalah & aparat & merupakan & salah \\
negara, matanya & satu & aparat \\
adalah & mata & kepolisian. Sebagai \\
Indonesia” & & salah satu penyidik \\
& KPK, maka ia \\
& menjadi salah satu \\
& mata dari Indonesia \\
& dalam melihat para \\
& koruptor. \\
\hline
\end{tabular}

Dalam kutipan di tabel 1, dikatakan bahwa Novel Baswedan merupakan aparat negara. Secara referensial, Novel Baswedan merupakan penyidik tetap KPK di tahun 2014. Selain itu, Novel juga merupakan aparatur negara yang berada di dinas kepolisian. Matanya adalah mata Indonesia, ditinjau dari segi maknanya pernyataan tersebut memiliki makna yang luas dan bersifat konotatif. Artinya tidak terpatok pada mata secara fisik saja tetapi juga mencakup kemampuan yang memiliki dampak bagi Indonesia, sehingga muncul "mata Indonesia".

Tabel 2. Analisis Makna Narasi Najwa Shihab

\begin{tabular}{|c|c|}
\hline Narasi & Makna \\
\hline $\begin{array}{l}\text { "Jika negara } \\
\text { gagal melindungi } \\
\text { aparatnya, } \\
\text { bagaimana negara } \\
\text { bisa mengurusi } \\
\text { kawula." }\end{array}$ & $\begin{array}{l}\text { Hampir setahun berlalu } \\
\text { sejak kasus penyiraman } \\
\text { air keras ke wajah } \\
\text { Novel } \text { Baswedan, } \\
\text { namun belum } \\
\text { ditemukan pelakunya. } \\
\text { Negera dinyatakan } \\
\text { gagal dalam kasus } \\
\text { tersebut. Jika seorang } \\
\text { aparat negara saja tidak } \\
\text { terjamin } \\
\text { perlindungannya, } \\
\text { bagaimana dengan } \\
\text { masyarakat umum? }\end{array}$ \\
\hline
\end{tabular}

Kalimat tersebut ditinjau dari segi kemaknaan, bersifat denotasi. Karena adanya acuan, bahwa aparat adalah penegak hukum, pelindung masyarakat yang ditugaskan negara. Jika pelindung tidak terlindungi, maka tidak ada yang dapat melindungi masyarakat. Kalimat ini juga bersifat informasional kognitif, karena memunculkan sebuah realita dimana negara tidak bisa melindungi Novel Baswedan sebagai seorang aparat negara.

Tabel 3. Analisis Makna Narasi Najwa Shihab

\begin{tabular}{|c|c|}
\hline Narasi & Makna \\
\hline $\begin{array}{l}\text { "Mata itu sedang } \\
\text { sakit dan melepuh, } \\
\text { daya pandangnya } \\
\text { terancam merapuh. }\end{array}$ & $\begin{array}{lr}\text { Kondisi } & \text { penglihatan } \\
\text { Novel } & \text { Baswedan } \\
\text { sejak } & \text { kejadian } \\
\text { penyiraman air keras }\end{array}$ \\
\hline $\begin{array}{lr}\text { Retina bisa saja } \\
\text { bikin ringkih, } \\
\text { namun optimisme } \\
\text { tak boleh menyisih." }\end{array}$ & $\begin{array}{ll}\text { menjadi } & \text { rusak. } \\
\text { Walaupun } & \text { begitu, ia } \\
\text { tetap } & \text { semangat } \\
\text { dalam } & \text { menjalani } \\
\text { hari-hari. } & \end{array}$ \\
\hline
\end{tabular}


Dalam arti sempit, kedua kalimat tersebut dapat dimaknai secara denotasi dimana kondisi penglihatan Novel Baswedan memang tidak lagi baik. Namun kalimat kedua juga bisa dimaknai secara luas, yang menandakan bahwa kondisi di kalimat pertama tidak mempengaruhi optimisme subjek (Novel Baswedan).

Tabel 4. Analisis Makna Narasi Najwa Shihab

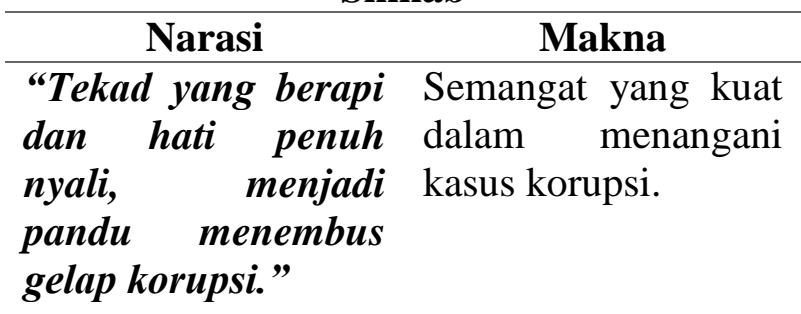

Kalimat tersebut jika dipahami dari segi konotatif berarti adanya semangat untuk menyelesaikan korupsi. Alasan, jalan untuk bisa keluar dari permasalahan korupsi dengan tekad yang kuat dan keberanian.

\section{Tabel 5. Analisis Makna Narasi Najwa} Shihab

\begin{tabular}{lll}
\hline \multicolumn{2}{c}{ Narasi } & \multicolumn{2}{c}{ Makna } \\
\hline "Publik jangan & Pemerintah tidak \\
dianggap sebelah & seharusnya \\
mata, kemarahan & mengabaikan \\
adalah energi tak & masyarakat. \\
terkira. & & Masyarakat bisa \\
Jika hanya marah & marah jika memang \\
yang kami punya, & harus, dan tak akan \\
kami akan marah & pernah menyerah. \\
demi & negeri & Kutipan ini lebih \\
tercinta. & seperti ungkapan \\
Kami adalah jutaan & dukungan untuk \\
mata yang selalu & Novel Baswedan. \\
nyalang, & kepal & Terlebih dengan lirik \\
tangan yang tak & lagu yang dibawakan \\
akan & mudah & di acara Mata Najwa. \\
tumbang." & \multicolumn{2}{l}{}
\end{tabular}

Pengertian kutipan tersebut jelas memiliki makna denotatif. Namun pada kalimat ketiga muncul makna idiomatik "Kami adalah jutaan mata yang selalu nyalang, kepal tangan yang tak akan mudah tumbang." Artinya merepresentasikan makna kalimat sebelumnya, bahwa masyarakat selalu memperhatikan dan akan siap berjuang. Tujuannya adalah untuk menciptakan sebuah perasaan bagi pembaca (makna piktorial). Kutipan ini lebih mengarah kepada aksi dukungan. Lagu yang dibawakan di acara Mata Najwa berisi kritikan kepada pihak berwajib yang belum juga mengusut tuntas kasus Novel Baswedan. Juga sebagai aksi dukungan kepada Novel, yang disampaikan dalam setiap lirik lagu. Lagu tersebut seolah menyatakan adanya kekecewaan dan amarah akan kasus Novel yang tidak selesai-selesai. Berharap kriminalitas tersebut dapat segera dituntaskan.

Maka dengan pencarian makna narasi Najwa Shihab berdasarkan kajian semantik dapat dibuktikan bahwa keseluruhan narasi cenderung menceritakan mengenai Novel Baswedan. Narasi memang dapat dikatana tendensius atau memihak. Hal ini karena topik yang dibahas memang keseluruhan mengangkat tragedi Novel Baswedan yang disiram air keras oleh orang tak dikenal, yang sampai setahun berselang belum berhasil ditangkap.

Namun tidak ada bagian narasi yang memiliki makna atau maksud menghina dan atau untuk merendahkan nama baik suatu pihak. Sedangkan UU ITE (Undang-Undang Informasi dan Transaksi Elektronik) yang mengatur mengenai hal yang dikomentari Hotman Paris ada di pasal 45 ayat (3) UU No. 19 Tahun 2016. Bunyinya" Setiap orang yang dengan sengaja dan tanpa hak mendistribusikan dan/atau mentransimisikan dan/atau membuat dapat diaksesnya Informasi Elektronik dan/atau Dokumen Elektronik yang memiliki muatan penghinaan dan/atau pencemaran nama baik sebagaimana dimaksud dalam pasal 27 ayat (3) dipidana dengan pidana penjara paling lama 4 (empat) tahun dan/atau denda paling banyak $R p$ 750.000.000,00 (tujuh ratus lima puluh juta rupiah)." Bahkan jika kutipan baris kedua seolah meragukan

\begin{tabular}{|l|l|l|l|l|l|}
\hline MEDAN MAKNA & Vol. XVI & No. 1 & HIm. 1 - 9 & Juni 2018 & ISSN 1829-9237 \\
\hline
\end{tabular}


negara, tetapi hal tersebut tidak dapat diterima sebagai kata yang menghina.

Apabila dimaknai dari sisi konotatif afektif, pernyataan Hotman Paris dapat dibenarkan mengenai tendensius, tetapi tidak dengan konteks penghinaan atau mencemarkan nama baik. Terlepas dari keseluruhan acara Mata Najwa, Hotman Paris hanya terfokus mengomentari narasi Najwa di akun instagramnya. Untuk itu, pembahasan ini dirasa dapat membuka wawasan mengenai kebahasaan untuk tidak sembarangan menyampaikan komentar yang sudah masuk kategori pengancaman.

\section{PENUTUP}

\subsection{Simpulan}

Dari hasil yang diperoleh pada pembahasan, dapat ditarik kesimpulan bahwa komentar Hotman Paris kepada narasi Najwa Shihab yang mengatakan bahwa narasi tersebut mengandung unsur tujuan untuk menjelekkan pemerintah sama sekali tidak dapat dibenarkan. Seperti telah dijelaskan, kutipan dari narasi-narasi tersebut menjelaskan kondisi Novel Baswedan. Bagaimana Novel setelah mendapat berbagai serangan masih tetap bertahan mengusut kasus korupsi. Bahkan setelah kasus penyiraman air keras ke wajahnya, pihak kepolisian yang adalah tempat asa Novel, belum mampu mengusut tuntas tragedi tersebut.

Narasi tersebut juga menyatakan bahwa rakyat marah akan keterlambatan penyelesaian kasus janggal itu. Hal ini tertera pada lirik lagu Efek Rumah Kaca yang berjudul "Sebelah Mata". Lagu tersebut didedikasikan sebagai ungkapan perasaan akan kejadian yang menimpa Novel Baswedan.

Sedangkan teguran yang disampaikan oleh Hotman Paris ialah terkait UU ITE. Pada komentarnya, Hotman Paris menyatakan "kepada para pesohor atau selebgram ahti-hati dalam membuat pernyataan. Jangan tendensius yang bisa mendiskreditkan negara dan aparatnya". Pada pernyataan tersebut, dapat dimaknai bahwa Hotman hendak mengatakan bahwa
Najwa berpihak kepada Novel Baswedan dan mendiskreditkan aparatur.

Walaupun tampak seperti Najwa berpihak kepada Novel baswedan, tetapi narasi tersebut tidak dapat diajukan sebagai pelanggaran UU ITE. Sebab tidak ada pernyataan dalam narasi tersebut yang mengarah kepada penghinaan yang mungkin dapat merendahkan, seperti yang diatur pada UU 19 Tahun 2016 tentang perubahan UU No.11 Tahun 2008 tentang Informasi dan Transaksi Elektronik. Dikatakan pada pasal 45 ayat (3), tentang larangan menghina atau mencemarkan nama baik.

Pemahaman akan makna konotasi afektif mungkin akan terjadi pada proses pemaknaan narasi tersebut yang mengarah pada sikap tendensius pada Novel. Tetapi hal tersebut tidak diatur pada UU ITE, sedangkan dalam narasi tidak tertera katakata yang dapat secara langsung atau tidak langsung menghina aparat atau pemerintah. Sehingga dengan begitu dapat dikatakan bahwa komentar Hotman Paris Hutapea tidak dapat direalisasikan, terkait ancaman UU ITE.

\subsection{Saran}

Penelitian ini membuktikan bahwa kerap kali masyarakat gagal memahami secara mendalam makna sebuah pernyataan. Maraknya kasus-kasus kesalahpengertian makna perlu kembali diperhatikan oleh pemerintah. Hal ini menandakan bahwa masyarakat Indonesia masih perlu dibina kembali mengenai bahasa Indonesia.

Bagi masyarakat, alangkah lebih baik ketika memahami terlebih dahulu sebuah pernyataan secara mendalam sebelum digugat. Karena tidak semua yang kita duga secara afektif bersifat menghina, bermakna menghina di kajian bahasa. Perlu diterapkan kepada masyarakat untuk lebih berhati-hati dalam menggunakan bahasa, maupun menggugat sebuah pernyataan.

\section{Daftar pustaka}

\section{Buku}

Leech, Geoffrey (penerjemah Paina Partama). 2003. Semantik. Yogyakarta: Pustaka Pelajar. 
Parera, J.D. 2004. Teori Semantik. Jakarta: Erlangga.

Pateda, Mansoer. 2001. Semantik Leksikal. Jakarta: PT Rineka Cipta.

\section{Artikel}

Juniar, Netti Titin. 2013. Analisis Makna Kontekstual pada Iklan Niaga di Harian Analisa Medan. Skripsi publikasi. Medan: Jurusan Bahasa dan Sastra Indonesia Universitas Negeri Medan.

Mahmudi, Ali. 2015. Analisis Makna pada Status BBM (Blackberry Mesenger) di Kalangan Remaja: Tinjauan Semantik. Skripsi publikasi. Surakarta: Pendidikan Bahasa Indonesia Universitas Muhammadiyah Surakarta. Prasanti, Sella. 2015. Analisis Makna Semantik pada Kring Solopos Edisi Bulan November 2014: Kajian Semantik. Skripsi publikasi. Surakarta: Pendidikan Bahasa Indonesia Universitas Muhammadiyah Surakarta.

Pelawi, Bena Yusuf. 2009. Aspek Semantik dan Pragmatik dalam Penerjemahan. Artikel publikasi Jurnal LINGUA
CULTURA Vol.3 No.2 November 2009: 146-151.

Silalahi, Roswita. 2005. Makna dan Konteks dalam Bahasa Batak Toba. Artikel publikasi ENGLONESIAN: Jurnal Ilmiah Linguistik dan Sastra, Vol.1, No.1, Mei 2005: 7-18.

Said, Ikhwan M. 2012. Kajian Semantik Terhadap Produk Hukum Tertulis di Indonesia. Artikel publikasi jurnal MIMBAR HUKUM Vol. 24, No. 2, Juni 2012: 187-375.

\section{Internet:}

Naren, Dian. 2018, "Gara-gara Kalimat Ini,Hotman Paris Peringatkan Soal UU ITE Kepada Najwa Shihab?" dalam wow.tribunnews.com/2018/03/02, diakses 6 Maret 2018.

Resmini, Novi. Bahan Belajar Mandiri VIII, Unsur Semantik dan Jenis Makna dalam artikel online file.upi.edu, diakses pada tanggal 21 Februari 2017.

Shihab, Najwa. 2018. Kami Bersama Novel: Novel Baswedan Kembali, dalam https://youtu.be/0ulbqGUSQA, diakses 7 2018. 